\title{
Volatile anesthetics regulate pulmonary vascular tension through different potassium channel subtypes in isolated rabbit lungs
}

\author{
[Les anesthésiques volatils maintiennent la tension vasculaire pulmonaire par \\ différents sous- types de canaux potassiques dans des poumons de lapins isolés]
}

Renyu Liu MD PhD, ${ }^{*}$ Yuichi Ishibe MD PhD, ${ }^{*}$ Naoto Okazaki PhD, ${ }^{*}$ Mayumi Ueda MD PhD, $†$ Juichi Hirosawa MD

Background: The effects of volatile anesthetics on subtypes of $\mathrm{K}^{+}$ channels located on pulmonary vessels remain largely unexplored.

Methods: To investigate whether or not potassium channels play a role in the effect of volatile anesthetic on pulmonary vessels, isolated and perfused rabbit lungs were divided into four groups $(n=7$ each): a control group without treatment, a glibenclamide (Glib) group treated with adenosine triphosphate-sensitive $\mathrm{K}^{+}\left(\mathrm{K}_{\text {ATP }}\right)$ channel inhibitor, a 4-aminopyridine (4-AP) group treated with voltage-sensitive $\mathrm{K}^{+}\left(\mathrm{K}_{\mathrm{V}}\right)$ channel inhibitor, and an iberiotoxin (IbTX) group treated with high conductance calcium-activated $\mathrm{K}^{+}\left(\mathrm{K}_{\mathrm{Ca}}\right)$ channel inhibitor. After inhibitor administration and stabilization, two minimum alveolar concentration (MAC) of halothane, enflurane, isoflurane, or 1.8 MAC of sevoflurane were randomly administered for 15 min followed by eight minutes of fresh gas mixture after each agent inhalation.

Results: Isoflurane did not change pulmonary vascular tension in the control group but instead constricted the pulmonary vessels when $K_{v}$ channels were inhibited with 4-AP; constrictive effects of enflurane and halothane were observed on pulmonary vessels, and were enhanced by $K_{v}$ channel inhibition with 4-AP, but they were inhibited by $K_{C a}$ channel inhibition with IbTX; the dilation effect of sevoflurane was observed on pulmonary vessels but was not significantly affected by any of the $\mathrm{K}^{+}$channel inhibitors.

Conclusion: Halothane, enflurane and isoflurane, but not sevoflurane, regulate pulmonary vascular tension through $\mathrm{K}_{\mathrm{V}}$ and/or $\mathrm{K}_{\mathrm{Ca}}$ channels in isolated rabbit lungs.
Objectif : Les effets des anesthésiques volatils sur des sous-types de canaux $\mathrm{K}^{+}$des vaisseaux pulmonaires sont encore largement inexplorés. Nous avons voulu vérifier si les canaux potassiques jouent un rôle dans l'effet de ces anesthésiques sur les vaisseaux pulmonaires.

Méthode : Nous avons isolé et perfusé des poumons de lapins. Nous les avons divisés en quatre groupes ( $n=7$ chacun) : un groupe témoin sans traitement, un groupe glibenclamide (Glib) traité avec un inhibiteur de canal $K^{+}$sensible à l'adénosine triphosphate $\left(K_{\text {ATP }}\right)$, un groupe 4- aminopyridine (4-AP) traité avec un inhibiteur de canal $K^{+}$sensible au voltage $\left(K_{V}\right)$ et un groupe ibériotoxine (IbTX) traité avec un inhibiteur de canal $K^{+}$activé par le calcium à conductance élevée $\left(K_{C d}\right)$. Après l'administration et la stabilisation de l'inhibiteur, nous avons donné deux concentrations alvéolaires minimales (CAM) d'halothane, d'enflurane, d'isoflurane ou I,8 CAM de sévoflurane de façon aléatoire pendant 15 min, puis un mélange de gaz frais pendant 8 min après chaque agent d'inhalation.

Résultats : L'isoflurane n'a pas modifié la tension vasculaire pulmonaire dans le groupe témoin, mais a resserré les vaisseaux pulmonaires quand les canaux $K_{v}$ ont été inhibés par 4-AP. Les effets constrictifs de l'enflurane et de l'halothane sur les vaisseaux pulmonaires ont été observés et augmentés par l'inhibition du canal $K_{v}$ avec 4-AP, mais empêchés par l'inhibition du canal $K_{C a}$ avec IbTX. L'effet de dilatation du sévoflurane sur les vaisseaux pulmonaires a été observé, mais n'a pas été modifié significativement par aucun des inhibiteurs de canal $K+$.

Conclusion : L'halothane, l'enflurane et l'isoflurane, mais non le sévoflurane, maintiennent la tension vasculaire pulmonaire par les canaux $K_{V}$ et/ou $K_{C a}$ dans des poumons de lapins isolés.

From the Department of Anaesthesiology and Reanimatology, ${ }^{*}$ Tottori University Faculty of Medicine, Tottori, Yonago, and the Department of Anaesthesia, $\nmid$ Toyooka Hospital, Toyooka, Hyogo, Japan.

Address correspondence to: Dr. Renyu Liu, Department of Anaesthesia, University of Pennsylvania, 3400 Spruce Street, 7th Dulles,

Philadelphia, Pennsylvania 19104-4283, USA. E-mail: liu@mail.med.upenn.edu

Financial support: support was provided from institutional and department sources.

Accepted for publication August 20, 2002.

Revision accepted November 29, 2002. 
$\mathrm{V}$ ARIOUS subtypes of $\mathrm{K}^{+}$channels are located on pulmonary vascular smooth muscle cells including voltage-dependent $\mathrm{K}^{+}\left(\mathrm{K}_{\mathrm{V}}\right)$ channels, adenosine triphosphate (ATP)-sensitive $\mathrm{K}^{+}\left(\mathrm{K}_{\mathrm{ATP}}\right)$ channels and calcium-activated $\mathrm{K}^{+}\left(\mathrm{K}_{\mathrm{Ca}}\right)$ channels. ${ }^{1}$ The effects of volatile anesthetics on $\mathrm{K}_{\mathrm{v}}$ and $\mathrm{K}_{\mathrm{Ca}} \mathrm{K}^{+}$channels located on pulmonary vessels remain largely unexplored. Some $\mathrm{K}^{+}$channel inhibitors have already been used clinical$1 \mathrm{y}^{2}$ and the activity of $\mathrm{K}^{+}$channels may change in certain pathophysiological conditions. ${ }^{3}$ Therefore, it becomes clinically relevant to investigate if volatile anesthetics affect pulmonary vessels through $\mathrm{K}^{+}$channels. We have demonstrated previously that isoflurane (not sevoflurane) modulates pulmonary vascular response through $\mathrm{K}_{\mathrm{V}}$ and $\mathrm{K}_{\mathrm{Ca}}$ channels during hypoxia. ${ }^{4}$ In the present study, we hypothesized that different inhaled anesthetics may affect pulmonary tension differently in the presence or absence of potassium channel inhibitors under normoxic conditions. The hypothesis was tested in isolated perfused rabbit lungs.

\section{Materials and methods Isolated lung preparation}

The experimental protocol was approved by the Tottori University Faculty of Medicine Laboratory Animal Care Committee. Twenty-eight female Japanese white rabbits $(2.0-2.5 \mathrm{~kg})$ were anesthetized with pentobarbital $\left(20 \mathrm{mg} \cdot \mathrm{kg}^{-1}\right.$, intravenously) and ketamine (30 $\mathrm{mg} \cdot \mathrm{kg}^{-1}$, intramuscularly). The lungs were isolated and perfused as described previously.,

\section{Experimental protocol}

Following commencement of perfusion and ten minutes for stabilization, the lungs were divided into four groups in random order ( $n=7$, each) according to the $\mathrm{K}^{+}$channel subtype inhibitor added into the perfusate from the reservoir. In the control group, no channel inhibitor was added. In the glibenclamide (Glib) group, the perfusate contained $10 \mu \mathrm{M}$ Glib, a highly selective $\mathrm{K}_{\mathrm{ATP}}$ channel inhibitor. In the iberiotoxin (IbTX) group, the perfusate contained $45 \mathrm{nM}$ of IbTX, a highly selective inhibitor of $\mathrm{K}_{\mathrm{Ca}}$ channels. In the 4-aminopyridine (4-AP) group, the perfusate contained $1 \mathrm{mM}$ of $4-\mathrm{AP}$, a $\mathrm{K}_{\mathrm{V}}$ channel inhibitor. Twenty minutes elapsed for stabilization after inhibitor administration, then two minimum alveolar concentrations (MAC) of halothane $(2.8 \%)$, sevoflurane $(7.4 \%)$, isoflurane $(4.0 \%)$, or $1.8 \mathrm{MAC}$ enflurane $(5.3 \%)$ were randomly administered for $15 \mathrm{~min}$. The lungs were ventilated without volatile agent for eight minutes to wash out the anesthetic after each agent inhalation and to allow the pulmonary vascular tension to return

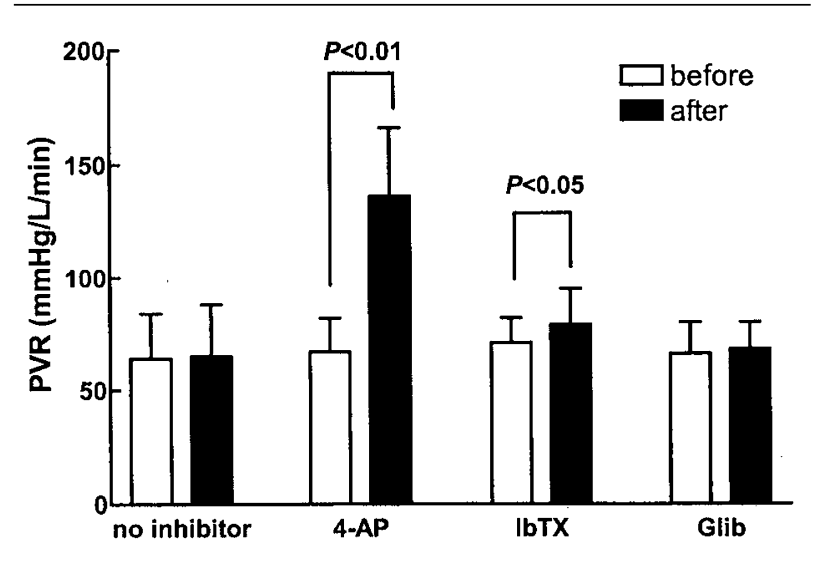

FIGURE I Pulmonary vascular resistance (PVR) change before and after inhibitor administration. 4-AP $=4$-aminopyridine; IbTX = iberitoxin; Glib = glibenclamide; before $=$ before inhibitor administration; after $=$ after inhibitor administration.

to the pre-inhalation value. Halothane, enflurane, isoflurane, or sevoflurane was administered using an agent specific vaporizer and monitored with an anesthetic gas monitor.

The pulmonary vascular resistance (PVR) was determined before and after each inhibitor or anesthetic administration. Total PVR (Rt), pulmonary arterial resistance $(\mathrm{Ra})$ and pulmonary venous resistance $(\mathrm{Rv})$ were determined as described previously. ${ }^{4}$

Data are presented as mean \pm SD. Within-group differences were analyzed using one-way analysis of variance (ANOVA) with repeated measures (Statview 4.5, Abacus Concepts, Berkeley, CA, USA). Pre- and post-agent administration comparison was performed with a t test. Multiple samples at the same time intervals were analyzed using one-way ANOVA. The differences in resistance among groups for each volatile anesthetic were analyzed with post hoc comparisons. Scheffe's test was used for post hoc comparisons. A $P$ $<0.05$ was considered significant.

\section{Results}

Effects of $\mathrm{K}^{+}$channel inhibitors on PVR (Figure $\mathrm{I}$ )

There was no significant difference in PVR among groups before $\mathrm{K}^{+}$channel inhibitor administration. PVR increased after 4-AP and IbTX administration, but did not change significantly after Glib administration.

\section{Effects of volatile anesthetics on PVR in the absence of channel inbibitors}

Pulmonary pressures and PVR returned to pre-inhalation values after washout of the volatile anesthetics. There was no significant difference in resistance before 
TABLE I Changes in pressure and resistance in the control group

\begin{tabular}{|c|c|c|c|c|c|c|c|c|}
\hline & \multicolumn{2}{|c|}{ Halothane } & \multicolumn{2}{|c|}{ Enflurane } & \multicolumn{2}{|c|}{ Isoflurane } & \multicolumn{2}{|c|}{ Sevoflurane } \\
\hline & Before & After & Before & After & Before & After & Before & After \\
\hline Ppa & $10.4 \pm 1.1$ & $11.8 \pm 1.2 \#$ & $10.5 \pm 1.1$ & $12.4 \pm 1.3 \#$ & $10.8 \pm 1.0$ & $10.8 \pm 1.0$ & 10.51 .0 & $10.0 \pm 0.7^{*}$ \\
\hline Ppv & $5.4 \pm 0.9$ & $5.5 \pm 1.0$ & $5.3 \pm 0.9$ & $5.4 \pm 1.0$ & $5.4 \pm 0.9$ & $5.5 \pm 1.0$ & $5.4 \pm 0.9$ & $5.4 \pm 1.0$ \\
\hline Pdo & $7.9 \pm 0.5$ & $8.4 \pm 0.7$ & $8.0 \pm 0.8$ & $8.5 \pm 0.7$ & $7.8 \pm 0.5$ & $8.0 \pm 0.5$ & $8.0 \pm 0.8$ & $7.8 \pm 0.5$ \\
\hline Flow & $83.6 \pm 2.3$ & 83.02 .5 & $83.7 \pm 2.5$ & $83.0 \pm 2.8$ & $82.9 \pm 3.2$ & $82.9 \pm 2.9$ & $83.4 \pm 2.7$ & $84.0 \pm 2.5$ \\
\hline Rt & $60 \pm 22$ & $76 \pm 25 \#$ & $62 \pm 22$ & $84 \pm 27 \#$ & $66 \pm 22$ & $65 \pm 24$ & $62 \pm 22$ & $55 \pm 20^{*}$ \\
\hline $\mathrm{Ra}$ & $31 \pm 16$ & $41 \pm 20 \#$ & $30 \pm 20$ & $46 \pm 22 \#$ & $36 \pm 15$ & $35 \pm 16$ & $30 \pm 17$ & $26 \pm 12 *$ \\
\hline $\mathrm{Rv}$ & $30 \pm 9$ & $35 \pm 9$ & $32 \pm 4$ & $38 \pm 7$ & $29 \pm 9$ & $30 \pm 8$ & $31 \pm 7$ & $29 \pm 9$ \\
\hline
\end{tabular}

Data are mean $\pm \mathrm{SD} ; \mathrm{n}=7 .{ }^{*} \mathrm{P}<0.05$ vs the value before inhalation; $\# \mathrm{P}<0.01$ vs the value before inhalation. Ppa $(\mathrm{mmHg})=$ pulmonary artery pressure; $\mathrm{Ppv}(\mathrm{mmHg})=$ pulmonary venous pressure; Pdo = double occlusion pressure; flow $\left(\mathrm{mL} \cdot \mathrm{min}^{-1}\right)=$ perfusion flow; Rt $\left(\mathrm{mmHg} \cdot \mathrm{L}^{-1} \cdot \mathrm{min}^{-1}\right)=$ total pulmonary vascular resistance; $\mathrm{Ra}\left(\mathrm{mmHg} \cdot \mathrm{L}^{-1} \cdot \mathrm{min}^{-1}\right)=$ pulmonary artery resistance; $\mathrm{Rv}\left(\mathrm{mmHg} \cdot \mathrm{L}^{-1} \cdot \mathrm{min}^{-1}\right)=\mathrm{pul}-$ monary venous resistance.

TABLE II Changes in pulmonary resistance after anesthetic administration in the presence of channel inhibitors

\begin{tabular}{|c|c|c|c|c|c|c|}
\hline \multirow{2}{*}{$\begin{array}{l}\text { Resistance } \\
\left(m m H g \cdot m L^{-1} \cdot m^{-1}\right)\end{array}$} & \multicolumn{2}{|c|}{$4-A P$} & \multicolumn{2}{|c|}{$I b T X$} & \multicolumn{2}{|c|}{ Glib } \\
\hline & Pre-inbalation & Post-inbalation & Pre-inbalation & Post-inhalation & Pre-inbalation & Post-inbalation \\
\hline Halothane & $142 \pm 25$ & $172 \pm 29 \#$ & $83 \pm 20$ & $87 \pm 22^{*}$ & $67 \pm 9$ & $81 \pm 8 \#$ \\
\hline Enflurane & $137 \pm 22$ & $207 \pm 33 \#$ & $78 \pm 16$ & $87 \pm 16^{*}$ & $69 \pm 10$ & $88 \pm 13 \#$ \\
\hline Isoflurane & $137 \pm 29$ & $173 \pm 30 \#$ & $81 \pm 18$ & $74 \pm 13$ & $66 \pm 12$ & $71 \pm 7$ \\
\hline Sevoflurane & $141 \pm 21$ & $132 \pm 17^{*}$ & $80 \pm 17$ & $68 \pm 13^{*}$ & $67 \pm 9$ & $59 \pm 9 \#$ \\
\hline
\end{tabular}

Data are mean $\pm \mathrm{SD} ; n=7 .{ }^{*} P<0.05$ vs the value before inhalation; $\# P<0.01$ vs the value before inhalation.; 4-AP $=4$-aminopyridine; $\mathrm{IbTX}=$ iberitoxin; Glib = glibenclamide.

each anesthetic administration within the control group. Pulmonary vascular effects varied between volatile anesthetics. Enflurane and halothane significantly increased Ra and Rt. Sevoflurane decreased PVR. Isoflurane did not show any significant effect on PVR (Table I).

The effect of volatile anesthetics on PVR in the presence of $\mathrm{K}^{+}$channel inbibitors

Both halothane and enflurane constricted pulmonary vessels in the presence of 4-AP, IbTX, or Glib; isoflurane constricted pulmonary vessels only in the prescence of 4-AP; sevoflurane dilated pulmonary vessels in the presence of all the investigated channel inhibitors (Table II). The absolute increase in resistance with halothane was augmented by $4-\mathrm{AP}$, inhibited by IbTX, but not significantly affected by Glib. The absolute increase in resistance with enflurane was enhanced by 4$\mathrm{AP}$, but not affected by IbTX or Glib. Isoflurane constricted the pulmonary vessels only when $\mathrm{K}_{\mathrm{v}}$ channels were inhibited by 4 -AP. The pulmonary dilator effect of sevoflurane was not significantly affected by any of the $\mathrm{K}^{+}$channel inhibitors (Figure 2).

\section{Discussion}

The effect of anesthetics on pulmonary vessels was investigated in the presence of three subtypes of potassium channel inhibitors. Despite the presence of several subtypes of $\mathrm{K}_{\mathrm{V}}$ channels in the pulmonary vessels, ${ }^{6}$ the 4-AP-sensitive $\mathrm{K}_{\mathrm{V}}$ channel was investigated in the present study. The results clearly indicate that both 4AP-sensitive $\mathrm{K}_{\mathrm{V}}$ channels and $\mathrm{K}_{\mathrm{Ca}}$ channels regulate basal pulmonary arterial tone.

The vasodilation of cerebral ${ }^{7}$ and mesenteric vessels ${ }^{8}$ induced by isoflurane and sevoflurane appears to be mediated via the activation of $\mathrm{K}_{\mathrm{ATP}}$ channels. In the present study, however, the effect of volatile anesthetics on pulmonary vascular tension was not affected by $\mathrm{K}_{\text {ATP }}$ channel inhibition. It is therefore likely that volatile anesthetics did not affect basal vascular tension through $\mathrm{K}_{\mathrm{ATP}}$ channels in the pulmonary vessels.

Although $\mathrm{K}_{\mathrm{V}}$ channels in mesenteric vessels are not affected by isoflurane, ${ }^{8}$ 4-AP-sensitive $\mathrm{K}_{\mathrm{V}}$ channels are suppressed reversibly by clinically relevant concentrations of halothane and isoflurane in canine coronary arteries. ${ }^{9}$ The results of the present study suggest that halothane, enflurane and isoflurane may regulate pulmonary vascular tension through $\mathrm{K}_{\mathrm{V}}$ channels. 


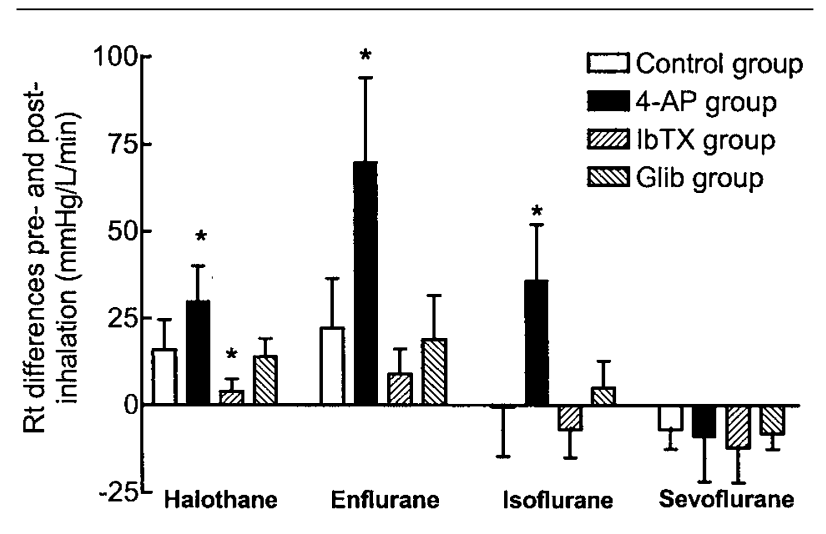

FIGURE 2 Total pulmonary vascular resistance (Rt) before and after anesthetic inhalation. See text for details. Data are mean \pm SD. $n=7$ per group. ${ }^{*} P<0.01$ vs control group. Rt difference $=$ resistance after anesthetic administration - (minus) resistance before anesthetic administration

Enflurane and halothane may inhibit $\mathrm{K}_{\mathrm{V}}$ channels or strengthen the inhibitory effect of channel inhibitors.

Volatile anesthetics affect $\mathrm{K}_{\mathrm{Ca}}$ channels in aortic endothelial cells ${ }^{10}$ and small mesenteric arteries. ${ }^{8}$ Our results suggest that halothane may also have significant effects on $\mathrm{K}_{\mathrm{Ca}}$ channels in pulmonary vessels. Since the constrictive effect of halothane on pulmonary vessels was attenuated by IbTX, it is likely that halothane may activate $\mathrm{K}_{\mathrm{Ca}}$ channels, and consequently hyperpolarize the membrane potential of smooth muscle cells.

In summary, pulmonary vascular effects vary between volatile anesthetics. Halothane constricted pulmonary vessels, and the constrictive effect was potentiated by $\mathrm{K}_{\mathrm{V}}$ channel inhibition (4-AP), attenuated by $\mathrm{K}_{\mathrm{Ca}}$ channel inhibition (IbTX), but not altered by $\mathrm{K}_{\mathrm{ATP}}$ channel inhibition (Glib). Enflurane constricted pulmonary vessels, and the constrictive effect was potentiated by $\mathrm{K}_{\mathrm{V}}$ channel inhibition, but not changed by $\mathrm{K}_{\mathrm{Ca}}$ or $\mathrm{K}_{\mathrm{ATP}}$ channel inhibition. Isoflurane, neither a vasoconstrictor nor dilator, constricted pulmonary vessels when $\mathrm{K}_{\mathrm{V}}$ channels were inhibited with 4-AP. Sevoflurane dilated pulmonary vessels, and dilation was not influenced by any $\mathrm{K}^{+}$channel subtype inhibitor in isolated rabbit lungs. The results suggest that halothane, enflurane, and isoflurane (but not sevoflurane) regulate pulmonary vascular tension through $\mathrm{K}_{\mathrm{V}}$ and/or $\mathrm{K}_{\mathrm{Ca}}$ channels in isolated rabbit lungs.

\section{Acknowledgement}

The authors thank Jason Keller for English grammar editing assistance.

\section{References}

1 Michelakis ED, Reeve HL, Huang JM, et al. Potassium channel diversity in vascular smooth muscle cells. Can J Physiol Pharmacol 1997; 75: 889-97.

2 Fox KM, Henderson JR, Kaski JC, et al. Antianginal and anti-ischaemic efficacy of tedisamil, a potassium channel blocker. Heart 2000; 83: 167-71.

3 Pellegrino M, Pellegrini M, Bigini P, Scimemi A. Properties of $\mathrm{Ca}^{2+}$-activated $\mathrm{K}^{+}$channels in erythrocytes from patients with myotonic muscular dystrophy. Muscle Nerve 1998; 21: 1465-72.

4 Lin R, Ueda M, Okazaki N, Ishibe $\Upsilon$. Role of potassium channels in isoflurane- and sevoflurane-induced attenuation of hypoxic pulmonary vasoconstriction in isolated perfused rabbit lungs. Anesthesiology 2001; 95: 939-46.

5 Ishibe $\Upsilon$, Gui X, Uno H, Shiokawa $\Upsilon$, Umeda $T$, Suekane $K$. Effect of sevoflurane on hypoxic pulmonary vasoconstriction in the perfused rabbit lung. Anesthesiology 1993; 79: 1348-53.

6 Yuan XJ, Wang J, Juhaszova M, Golovina VA, Rubin $L J$. Molecular basis and function of voltage-gated $\mathrm{K}^{+}$ channels in pulmonary arterial smooth muscle cells. Am J Physiol 1998; 274: L621-35.

7 Iida H, Ohata H, Iida M, Watanabe $\Upsilon$, Dohi S. Isoflurane and sevoflurane induce vasodilation of cerebral vessels via ATP-sensitive $\mathrm{K}^{+}$channel activation. Anesthesiology 1998; 89: 954-60.

8 Kokita N, Stekiel TA, Yamazaki M, Bosnjak ZJ, Kampine JP, Stekiel WJ. Potassium channel-mediated hyperpolarization of mesenteric vascular smooth muscle by isoflurane. Anesthesiology 1999; 90: 779-88.

9 Buljubasic N, Rusch NJ, Marijic J, Kampine JP, Bosnjak ZJ. Effects of halothane and isoflurane on calcium and potassium channel currents in canine coronary arterial cells. Anesthesiology 1992; 76: 990-8.

10 Simoneau C, Thuringer D, Cai S, Garneau L, Blaise G, Sawve $R$. Effects of halothane and isoflurane on bradykinin-evoked $\mathrm{Ca}^{2+}$ influx in bovine aortic endothelial cells. Anesthesiology 1996; 85: 366-79. 